\title{
Oil spill response-related injuries on sand beaches: when shoreline treatment extends the impacts beyond the oil
}

\author{
Jacqueline Michel $^{1, *}$, Stephen R. Fegley ${ }^{2}$, Jeffrey A. Dahlin ${ }^{1}$, Chip Wood $^{3}$ \\ ${ }^{1}$ Research Planning, Inc., Columbia, South Carolina 29201, USA \\ ${ }^{2}$ University of North Carolina at Chapel Hill, Institute of Marine Sciences, Morehead City, North Carolina 28557, USA \\ ${ }^{3}$ U.S. Fish and Wildlife Service, Houston, Texas 77058, USA
}

\begin{abstract}
Studies of oil spills on sand beaches have focused traditionally on the effects of shortterm oil exposure, with recovery of sand beach macrobenthic communities occurring within several weeks to several years. The Deepwater Horizon spill resulted in chronic, multi-year re-oiling and up to $4 \mathrm{yr}$ of extensive and often intensive treatments. Of the $965 \mathrm{~km}$ of sand beaches that were oiled, shoreline treatment was documented on $683 \mathrm{~km}$. Intensive mechanical treatment was conducted from 9 to $45 \mathrm{mo}$ after the initial oiling on $32.4 \mathrm{~km}$ of shoreline in Louisiana, and deep beach excavation/sifting and tilling was conducted along $60.5 \mathrm{~km}$ in Louisiana, Alabama, and Florida, often along contiguous lengths of beach. Recovery of sand beach invertebrate communities from the combined effects of oiling and treatment would likely be delayed by 2 to 6 yr after the last response action was completed. We introduce the concept of 'Response Injury' categories that reflect both intensity and frequency of beach treatment methods. We use the literature on similar types of disturbances to sand beach communities (foot traffic, vehicular traffic, wrack removal, beach nourishment) to describe the expected impacts. Temporal patterns of responserelated disturbances can affect seasonal recruitment of organisms and the overall rate of ecosystem recovery from both oil exposure and treatment disturbance. This concept provides a framework for specifically assessing response-related impacts in future spills, which has not been considered in previous injury assessments.
\end{abstract}

KEY WORDS: Deepwater Horizon - Oil spill · Sand beach - Shoreline treatment - Shoreline cleanup $\cdot$ Impact $\cdot$ Recovery

\section{INTRODUCTION}

Approximately $70 \%$ of the land-sea margin globally, and the predominate portion of the land-sea margin in the northern Gulf of Mexico, consist of exposed sand beaches (Rakocinski et al. 1991, Dugan et al. 2010). This generally narrow, but ubiquitous landform supports a diverse, but cryptic, biological community that, along with the physical structure of the beach, provides an array of ecosystem services, some of which are widely recognized and exploited commercially, some of which are not. The list of recognized

${ }^{*}$ Corresponding author: jmichel@researchplanning.com

${ }^{\S}$ Advance View was available online November 29, 2016 services provided by sand beaches includes: (1) sediment storage and transport; (2) wave dissipation and buffering during storms; (3) scenic vistas and recreation; (4) groundwater filtration; $_{i}(5)$ nutrient mineralization and recycling; (6) maintenance of biodiversity and genetic resources; (7) carbon transfer from primary producers and decomposers to species of broad public interest, such as birds and fish; and (8) functional links between terrestrial and marine environments (Defeo et al. 2009). Many of these services can be altered, diminished, or destroyed by oiling of the beach and shoreline cleanup actions to remove the oil.

(C) The authors 2017. Open Access under Creative Commons by Attribution Licence. Use, distribution and reproduction are unrestricted. Authors and original publication must be credited. 
The Deepwater Horizon (DWH) oil spill resulted in the oiling of $965 \mathrm{~km}$ of sand beach habitat from Florida to Texas, USA (Fig. 1; Nixon et al. 2016). Oil first began stranding in May 2010, which was soon followed by shoreline cleanups. Oil stranded in discontinuous waves over a 3 mo period, resulting in the incorporation of oil into the sediments in supratidal, intertidal, and nearshore subtidal habitats, at depths that could be greater than $1 \mathrm{~m}$ (Michel et al. 2013). Over time, these oiled sediments became remobilized, broken into oil:sediment balls, and subsequently were reburied as the beaches eroded and then accreted as part of the normal beach cycle. Most of the initial oil stranded when the beaches were in an eroded state, following a series of strong winter cold fronts from the prior year. Gulf beaches erode during the approach of these winter cold fronts by a combination of strong north winds that move sand from the backshore to the upper beach face, followed by southerly winds that transport some of the sand into the subtidal nearshore once the fronts have moved through (Dingler et al. 1992). Subsequent accretion following these erosional events deeply buried some of the DWH oil, which persisted in spite of the passage of several hurricanes (Michel et al. 2013). Beach profile data collected by field teams documented this post-oiling beach accretion from Louisiana to Texas (Deepwater Horizon SCAT Program unpubl. data). Removal of buried and exposed oil required extensive and prolonged uses of mechanical and manual treatments to meet cleanup endpoints. Cleanup endpoints were defined by a maximum amount of oil from the DWH spill (MC-252 oil) that could remain in the beach habitat (Table 1). On many beaches managed by federal agencies as part of national park lands or national wildlife refuges, the decision was made to have less stringent cleanup endpoints and forego intensive mechanical treatment.

Initially, most surface oil was removed using manual methods. However, by the fall of 2010, the Unified Command, composed of the US Coast Guard, BP, state, and local representatives responsible for directing the response, decided to use mechanical sifters to minimize sand removal, which was implemented mostly on amenity beaches in the 3 eastern states of Florida, Alabama, and Mississippi. The decision was made because of the large extent of shoreline to be cleaned, the deep burial of the oil, the patchy distribution of oiled sediments, the stringent cleanup endpoints for amenity beaches, and the push to open beaches in time for the 2011 tourist season. Mechanical sifting was conducted at night when the oiled sediments were cooler and less likely to break up as they passed through the screens. Night-time operations had the added potential impact to nocturnal fauna, such as sea turtles, ghost crabs, and wrack-associated species.

Another consequence of the deep burial of the oil was that most intensive removal operations were conducted in the supratidal zone. The large number of vehicles used during the response traveled mostly in the supratidal zone. Though efforts were made to restrict vehicles to certain corridors, incipient dune areas were heavily trafficked. Manual removal was conducted in all tidal zones. Many of the oiled sediments were referred to as surface residue balls, because they contained only about $10 \%$ oil but were cohesive. Long-reach tracked backhoes operated at the water line in the intertidal zone during efforts to remove submerged or buried oil:sediment mats from nearshore subtidal areas.

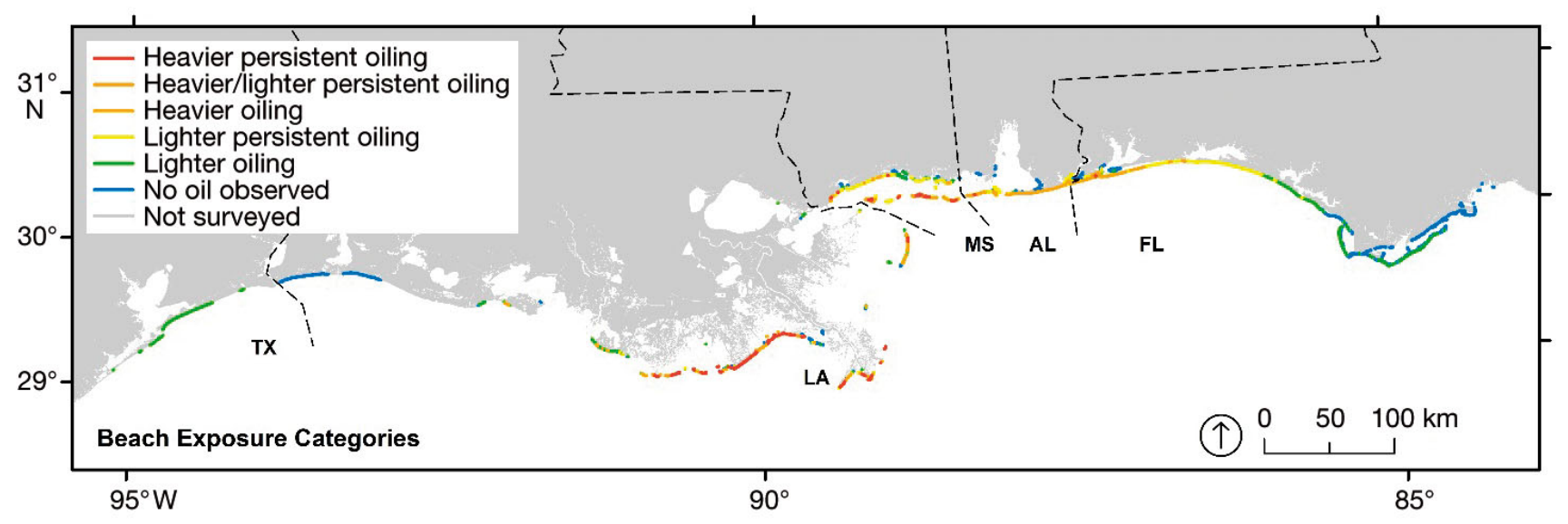

Fig. 1. Distribution of the maximum oiling category for all beaches affected by the Deepwater Horizon (DWH) oil spill. Compare with the maximum Response Injury (RI) in category per year (Fig. 6). See Nixon et al. (2016) for more detail on how oiling categories were defined and determined 
Table 1. Cleanup endpoints for sand beaches for the Deepwater Horizon oil spill. SRB: surface residue ball

\begin{tabular}{|c|c|c|}
\hline Shoreline type & Surface oil & Subsurface oil \\
\hline \multicolumn{3}{|l|}{ Eastern states: Florida, Alabama, Mississippi } \\
\hline Residential and amenity sand beaches & No visible MC-252 oil, or...* & No visible $\mathrm{MC}-252$ oil, or...* \\
\hline $\begin{array}{l}\text { Non-residential or non-amenity sand } \\
\text { beaches }\end{array}$ & $\begin{array}{l}<1 \% \text { visible surface oil and oiled } \\
\text { debris, and no SRBs }>5 \mathrm{~cm} \text { dia- } \\
\text { meter, or... }\end{array}$ & $\begin{array}{l}\text { No subsurface oil exceeding } 3 \mathrm{~cm} \text { in thick- } \\
\text { ness and patchy }(<50 \%) \text { distribution that } \\
\text { is greater than oil residue, or... }\end{array}$ \\
\hline $\begin{array}{l}\text { Beaches in special management areas } \\
\text { (state and federal wildlife refuges, } \\
\text { parks, wilderness areas) }\end{array}$ & $\begin{array}{l}\text { Subject to direction of special area } \\
\text { managers: }<1 \% \text { surface oil and } \\
\text { oiled debris, and no SRBs }>2.5 \mathrm{~cm} \text {, } \\
\text { or...* }\end{array}$ & $\begin{array}{l}\text { Subject to direction of special area man- } \\
\text { agers: no subsurface oil exceeding } 3 \mathrm{~cm} \text { in } \\
\text { thickness and patchy }(<50 \%) \text { distribution } \\
\text { that is greater than oil residue, or... }\end{array}$ \\
\hline \multicolumn{3}{|l|}{ Louisiana } \\
\hline Residential beaches & No visible oil that is $\mathrm{MC}-252$, or...* & $\begin{array}{l}\text { No visible MC-252 subsurface oil above } \\
\text { stain, or...* }\end{array}$ \\
\hline $\begin{array}{l}\text { Non-residential beaches and non- } \\
\text { federal special management areas }\end{array}$ & $\begin{array}{l}<1 \% \text { distribution of oil and oiled } \\
\text { debris, or...* }\end{array}$ & $\begin{array}{l}\text { No subsurface oil exceeding } 2.54 \mathrm{~cm} \text { in } \\
\text { thickness and patchy }(<50 \% \text { distribution) } \\
\text { that is greater than oil residue, or... }\end{array}$ \\
\hline $\begin{array}{l}\text { Beaches in federal special management } \\
\text { areas }\end{array}$ & $\begin{array}{l}<1 \% \text { surface oil and oiled debris, } \\
\text { or...* }\end{array}$ & No attempt to remove subsurface oil \\
\hline
\end{tabular}

Most mechanical removal operations in Florida, Alabama, and Mississippi were terminated by March 2011; however, mechanical removal methods were intermittently implemented until 2013 for some shorelines in Alabama. Due to beach erosion concerns in Louisiana, mechanical methods were initially used only on 1 amenity beach. However, mechanical excavation methods were extensively used both in the intertidal and supratidal zones in Louisiana during 2011 to 2012, to remove deeply buried oil that had persisted on several beaches through several hurricanes. Mechanical augers on small tracked vehicles were used extensively to delineate buried oil for removal; for example, nearly 38000 auger holes were excavated in a $10 \times 10 \mathrm{~m}$ grid between November 2012 and August 2013 on several beaches in Louisiana. Manual removal methods continued at different frequencies for years; active shoreline treatment operations were deemed complete in Florida, Alabama, and Mississippi in June 2013 (lasting 3 yr), and in Louisiana in April 2014 (lasting nearly 4 yr).

As part of the natural resource damage assessment (NRDA) for the DWH spill, the impacts of oil exposure and subsequent treatment activities on sand beach communities were assessed (Deepwater Horizon Natural Resource Damage Assessment Trustees 2016). Many of the papers in this Theme Section describe the field studies conducted for injury assessment of coastal resources. However, no field studies were conducted for sand beach faunal communities impacted by the spill for several reasons. First, the approach often used in past NRDA cases where sand beaches were oiled was to rely on: (1) maps of the degree of oiling based on data collected as part of the response to document exposure; (2) the literature to determine impacts by oiling category; and (3) the life histories of sand beach communities to predict recovery once the oil was removed. This approach, while expedient and effective for many spills, potentially underestimates the effects of extensive or intrusive response activities to the sand beach community. Second, the Trustees also had not anticipated the extended duration of repeated oil deposition nor the intensity and duration of response activities to remove the oil. This increased the complexity of integrating any potential sand beach faunal field studies over much of the northern Gulf of Mexico during the most critical time periods of the response. Finally, field survey study design was further complicated by a lack of baseline sand beach faunal community information for many of the impacted beaches. The Trustees determined it was more effective to consider alternative assessment strategies that relied on previously used techniques but also allowed them to consider intensity of disturbance on the beach community. Therefore, in the absence of any field measurements on species composition, abundance, or density in impacted versus control areas, the injury assessment had to be based on existing data, which consisted of (1) extensive documentation of oiling degree and duration, (2) detailed information on treatment methods, location, and duration, and (3) 
estimated impacts to beach macrofaunal communities from a synthesis and review of the literature for similar types of oiling and disturbances.

Bejarano \& Michel (2016) reviewed the oil spill literature on sand beaches and found that the extent of impacts and intervals to recovery vary according to the degree of oiling. Recovery intervals ranged from several weeks to several years, with longer recoveries for spills with long-term oil persistence or when there was no oil cleanup. Studies of 2 spills were considered most relevant because the oil weathered at sea during long-distance transport before stranding on shore: the 1979 Ixtoc 1 blowout of crude oil in the Gulf of Mexico which affected similar fauna in southern Texas; and the 2002 TV 'Prestige' spill of heavy fuel oil off Spain. For the Ixtoc 1 spill, Kindinger (1981) and Tunnell et al. (1982) report a wide range of survival of infauna from before and after the spill across the 13 beaches they sampled. At 7 of these 13 beaches, intertidal infauna abundances ranged from 85 to $97 \%$ lower after the spill. Three beaches showed a range from no change to modest increases in abundance $(0-19 \%)$. The remaining beaches decreased in intertidal infaunal abundance $(21-74 \%)$. For the 2002 TV 'Prestige' spill, de la Huz et al. (2005) and Junoy et al. (2005) reported decreases of 60 to $85 \%$ in the more abundant species; however, Junoy et al. $(2013,2014)$ concluded that recovery occurred within 1.5 yr. Even these most relevant case studies have limited value to injury quantification because of the following unique conditions for the DWH spill: (1) the extensive spatial scale of affected beaches; (2) the contiguity of oiled beaches over long distances; and (3) the extended time interval over which beaches continued to receive oil. Furthermore, because the DWH spill response included extensive and intensive sand beach treatment for up to $4 \mathrm{yr}$ after the initial oiling, we could not rely on the oil-impact literature alone for injury assessment. Therefore, we developed the concept of Response Injury (RI) as a category of sand beach injury to account for impacts from intensive and prolonged shoreline treatment to meet stringent shoreline cleanup endpoints during the DWH response, which had not been specifically addressed in previous injury assessments.

\section{METHODS}

\section{Compilation of the types of response disturbance}

Determination of response injuries followed a logical process (Fig. 2). The first step was to compile all available information on the types of response activi-

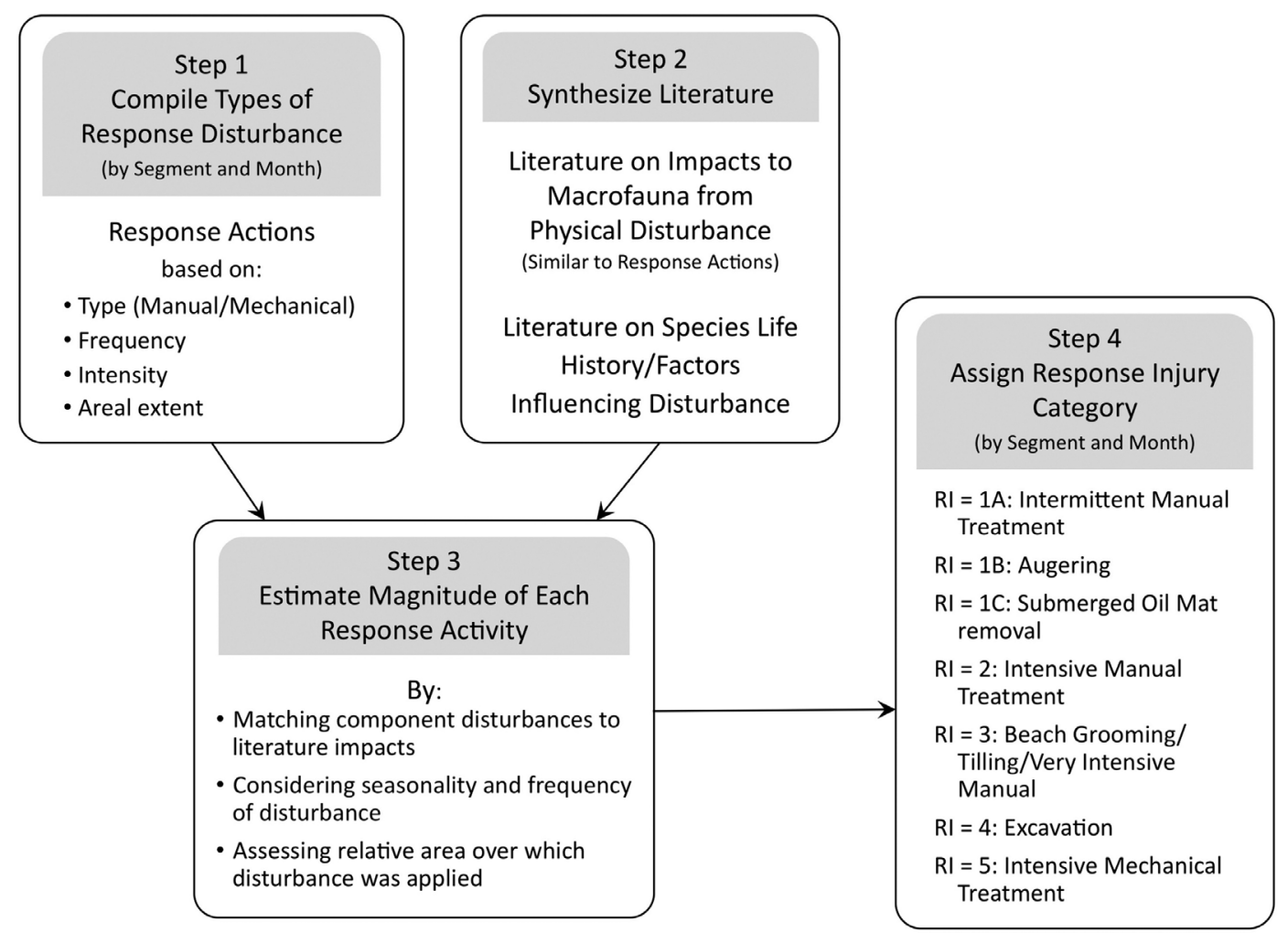

Fig. 2. Logical process for assigning Response Injury (RI) categories, as described in the 'Methods' (also see Table 3) 
ties conducted on sand beaches that would disturb beach fauna. The Operations Branch of the Response Organisation generated daily to weekly reports that documented the number of workers, type of equipment, pounds of material removed, and other information for each shoreline segment by day. These reports were less organized early in the response; however, there were many other types of reports generated by monitors that were used as well. Shoreline treatments were assigned and tracked based on shoreline segments that were established by the Deepwater Horizon Unified Command very early in the response. In Florida, Alabama, and Mississippi, shoreline segments were usually about $500 \mathrm{~m}$ long; in Louisiana, they could be several kilometers long. We compiled treatment method and the number of times it was conducted on a segment per month into spreadsheets for each state.

\section{Literature compilation}

Next (as shown in Fig. 2), an extensive array of published and unpublished documents was consulted to estimate the injuries induced by the types of response activities employed (described in detail by Michel et al. 2015). Literature searches were conducted using PubMed, Web of Science, Google Scholar, and other databases available through EndNote ${ }^{\circ}$ online search tools. Each citation was reviewed to select those most applicable. The EndNote ${ }^{\circledR}$ library for the references that we reviewed included over 200 papers (Bejarano et al. 2015); however, herein we cite the 39 most relevant references. We summarized key biological information of sand beach fauna in the northern Gulf of Mexico by beach zone, association with and use of wrack, role in trophic transfer, reproductive mode (bentho-pelagic or brooding), seasonality, and prey. The importance of life history in predicting expected recovery from oiling and response injuries resulting from the DWH oil spill is discussed by Michel et al. (2015).

\section{Literature on sand beach communities}

Based on our review of literature sand beach communities, Hooper (1981), Kindinger (1981), Rakocinski et al. (1991, 1998a,b), Yáñez-Arancibia \& Day (2004),
Cobb \& Arnold (2008), and Irlandi \& Arnold (2008) provided the most information relevant to northern Gulf of Mexico beaches. These studies show that sand beach macroinvertebrates live in a high-energy environment with frequent sand movement, and display a high degree of spatial and temporal variability that is controlled, in part, by wave energy, beach slope, grain size, salinity, and organic content. Globally, many studies (e.g. McLachlan \& Jaramillo 1995, Defeo \& McLachlan 2005, Dugan et al. 2011, Schlacher et al. 2008) have demonstrated that the structure and nature of the habitat, fauna, and services offered by the supratidal and intertidal (= supralittoral and littoral) differ substantially (Fig. 3). Considering these 2 beach zones separately is also required for our purposes, as most mechanical beach cleanup activities occurred in the supratidal zone, with the notable exceptions of where intertidal and subtidal oil mats were removed and dredging occurred, although manual removal occurred in all zones. Thus, separating the beach into supratidal and intertidal zones allowed us to assign a response injury to the appropriate spatial beach component.

The supratidal zone is the elevated portion of the beach where wrack accumulates because it is infrequently inundated by tides and wave run-up. Wrack, which generally consists of Sargassum, Spartina stems, and subtidal vascular grasses in the northern Gulf of Mexico, supports a community of invertebrates consisting of terrestrial, semi-terrestrial, and marine species. The terrestrial species (air-breathing species for which the majority of the life cycle occurs in terrestrial or freshwater habitats) include insects

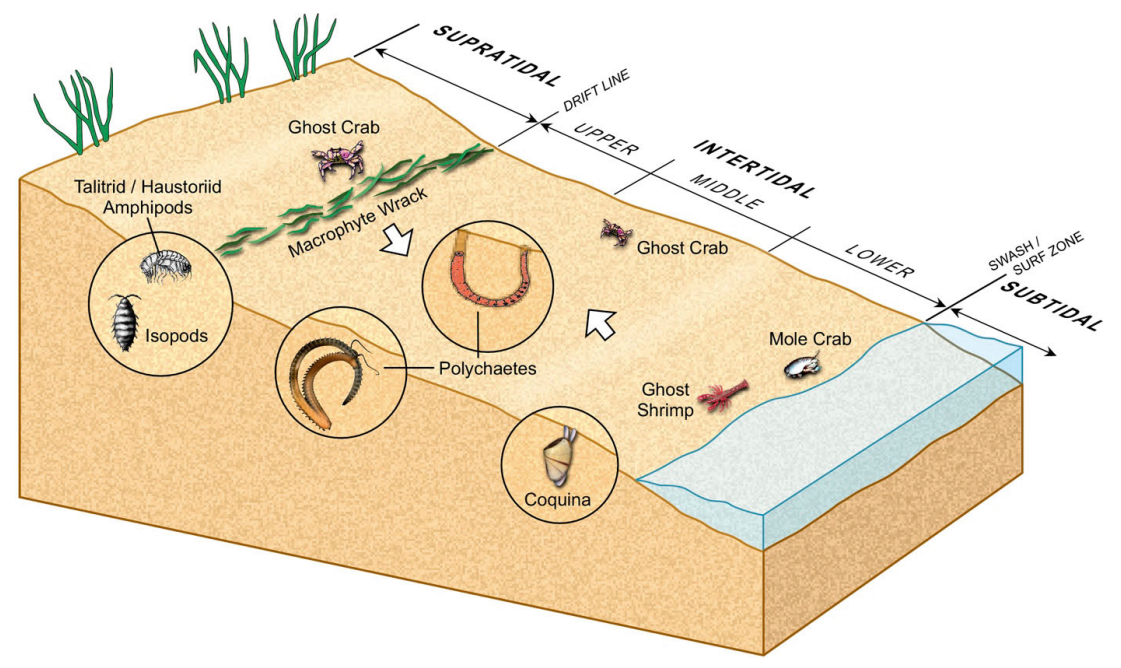

Fig. 3. Distribution of representative sand beach invertebrates. The 3 zones of the intertidal zone grade into each other and are not necessarily rigid in their extent. The fauna typical of the middle intertidal zone is a combination of those found in the upper and lower intertidal zones (represented by white arrows) 
(springtails, flies, beetles, and ants) and chelicerates (spiders and mites). The semi-terrestrial species (airbreathing through moistened gills but dependent on saline waters for part of their life cycle) include several species of talitrid amphipods and ghost crabs. The marine species (water-breathing through gills and dependent on saline waters for all of their life cycle) include haustorid amphipods and some polychaetes. These organisms shred the wrack while feeding and are, themselves, often consumed by shorebirds, passerines, and mammals. Wrack-associated organisms may comprise up to $40 \%$ of intertidal species and represent an important prey source for higher trophic levels (Dugan et al. 2003). Shredding of the wrack produces fine particulate organic matter that subsequently is degraded by bacteria, releasing the bound nutrients. Predation of this community primarily directs carbon transfer into terrestrial food webs. The supratidal community includes ghost crabs as well, although they do not depend directly on wrack because they are omnivores capable of feeding on marine and terrestrial plants and animals as well as on carrion.

The intertidal beach community differs from the supratidal community in species composition, nutritional foundation, and fate of trophic transfer. The standing invertebrate biomass in the intertidal greatly exceeds that occurring in the supratidal zone
(Raffaelli et al. 1991, Colombini \& Chelazzi 2003, Janssen \& Mulder 2005). In the northern Gulf of Mexico, the intertidal benthic community consists entirely of marine species and is dominated by coquinas, mole crabs, polychaetes, and haustorid amphipods. The majority of these species are suspension feeders relying on beach or surf diatoms as their primary source of nutrition. They are important prey for shorebirds. Fish, especially juveniles of several species, prey on these invertebrates when the beach is inundated. Consequently, trophic transfer of carbon and nutrients from this part of the beach enters into both terrestrial and marine food webs.

\section{Literature on response activity impacts}

For the different sand beach treatment activities used during the DWH response, component disturbances specific for that response were identified (Table 2), and the literature on similar types of disturbances was summarized. Intertidal communities on sand beaches are frequently considered tolerant to disturbances because the fauna are well-adapted to the dynamic beach environment. However, these fauna are directly impacted through cleanup operations by mortality from crushing and desiccation during sediment shifting and removal, and indirectly by

Table 2. Sand beach treatment method descriptions and expected associated impacts to sand beach biota and habitat. Intensity of disruption is represented as ${ }^{*}=$ minor $_{i *}{ }^{* *}=$ moderate $^{* * *}=$ major

\begin{tabular}{|lccccc|}
\hline Description & & & & & \\
\end{tabular}


altering habitat suitability (substrate compaction, wrack and shell removal), disrupting reproduction and recruitment patterns, and removing food supplies. Response activities during the DWH response were characterized by the 4 categories described below, though we note that these categories will vary depending on the spill-specific response methods.

\section{Foot traffic}

Persistent human trampling on beaches results in reduced faunal abundances. Noriega et al. (2012) showed consistent 10-fold decreases in ghost crab abundances between visited and unvisited beaches (actual densities changed inversely with intensity and frequency of human activity). Moffett et al. (1998) demonstrated experimentally that barefoot human traffic reduced the survival of softer-bodied crustaceans and juvenile bivalves in the lower intertidal. Compared to other disturbances, foot traffic effects appear moderate (McLachlan \& Brown 2006), although small losses in faunal abundances are consistently observed. Manual removal methods often involved intensive foot traffic (Fig. 4A) collateral with other disturbances (e.g. vehicular traffic, wrack removal, sifting) and occurred in all intertidal and supratidal zones.

\section{Off-road vehicle traffic}

Off-road traffic (4-wheelers, cars, and pickup trucks) on sand beaches has been studied extensively. These studies indicate that the effects of offroad traffic on local invertebrate assemblages vary greatly depending on their spatial and seasonal occurrence and abundance, and on their specific life histories. Schlacher et al. (2007) found that ghost crabs, with a soft exoskeleton, are frequently crushed by off-road traffic if their burrows are relatively shallow $(5 \mathrm{~cm})$; mortality declined exponentially with burrow depth. Those authors also found that ghost crab densities were higher in areas of low to moderate traffic, while individuals were smaller in heavily impacted areas, suggesting alterations of the population structure. Heavily trafficked beaches also had lower abundance, species richness, and diversity of intertidal macrobenthos, and strong changes in the community structure were driven by the low abundances of cirolanid isopods (Schlacher et al. 2008). Direct crushing appeared to be the main cause of community change.
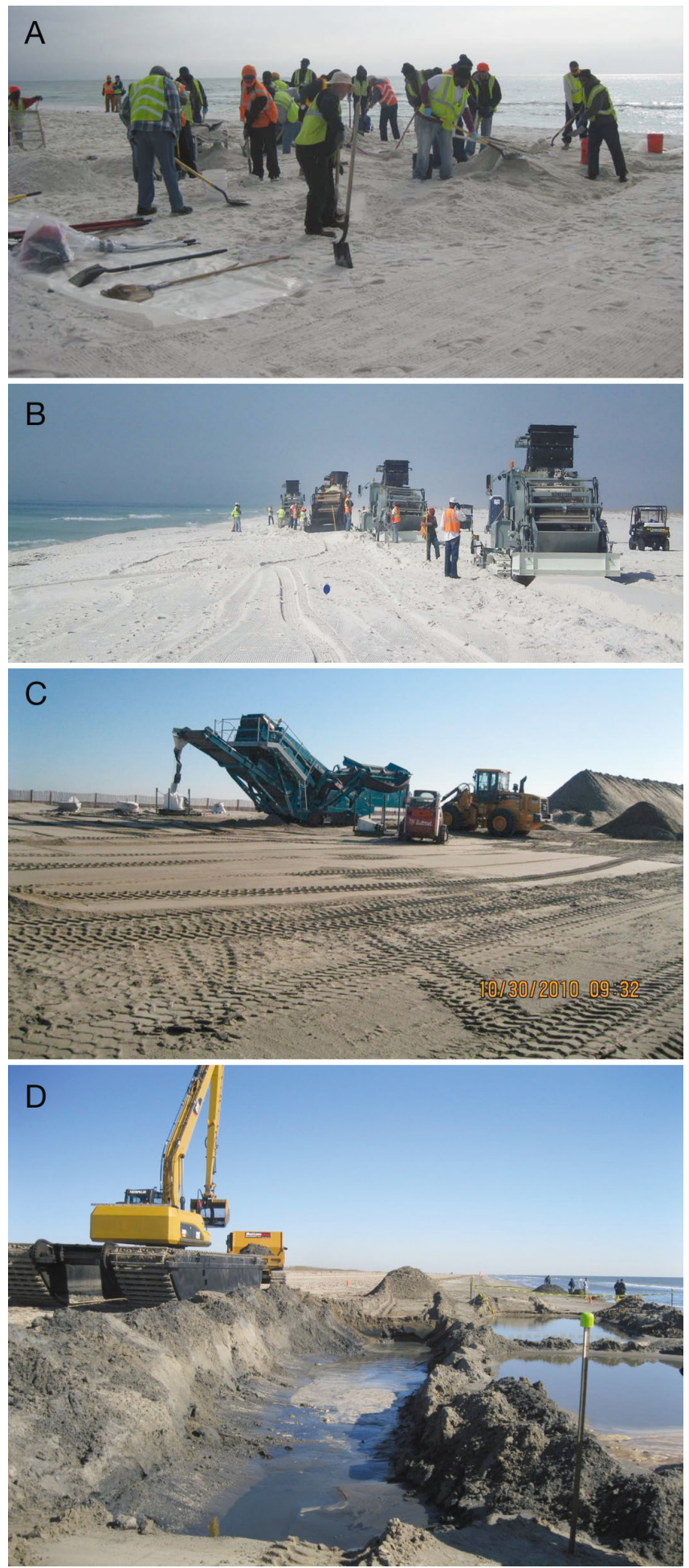

Fig. 4. Sand beach treatment methods. (A) Manual removal/ sifting to $15 \mathrm{~cm}$ at Ft. Pickens, Florida, January 2011. (B) Four 'Sand Sharks' at Ft. Pickens State Park, running in tandem and sifting to $45 \mathrm{~cm}$, February 2011. (C) Sifting of sediment piles created by mechanical removal on Grand Terre II, Louisiana, October 2010. (D) Excavation of oil mats at Elmers Island, Louisiana, December 2010 
Lucrezi \& Schlacher (2010) reported that sand beaches with traffic were slightly hotter and had lower moisture content than beaches closed to traffic, and not only were ghost crabs smaller, but also constructed much deeper and longer burrows, possibly to avoid desiccation. Kluft \& Ginsberg (2009) demonstrated that vehicle traffic can degrade beach wrack quality by crushing, scattering, or burying, thus impacting the survival of invertebrates that depend on this habitat for food and shelter. Open-beach species (i.e. beach hopper and wolf spider) were more susceptible to disturbance than wrack inhabitants (enchytraeid oligochaetes and tethinid flies). Gastropods, on the other hand, appeared to be more resistant than soft-bodied invertebrates (mysids and isopods) to vehicle traffic (van der Merwe \& van der Merwe 1991). Aside from direct crushing, heavy traffic decreases invertebrate abundance by reducing food availability (including wrack), increasing species displacement, disrupting the intertidal habitat and the physical properties of the sand substrate, and increasing invertebrate exposure to predators from the continuous maintenance of burrows (Schlacher et al. 2007, Kluft \& Ginsberg 2009). Many of these factors in turn can influence recruitment.

Compaction increases the bulk density of the substrate and reduces the interstitial space, thereby altering the capillarity, water retention, permeability, and exchange of gases and nutrients within the substrate (USACE 1989, Defeo et al. 2009). Compaction also increases the resistance to burrowing, which can impact burrowing behavior and reduce the abundance of burrowing fauna (Lindquist \& Manning 2001). The overall impacts of compaction can be translated into reduced substrate productivity and microhabitat suitability (Lindquist \& Manning 2001).

Beach grooming and wrack removal

Some of the mechanical beach cleaners used during the DWH response (Fig. 4B) were modified from those used for beach grooming on amenity beaches. While operated in a similar manner for beach grooming, these machines were set to extend 30 to $45 \mathrm{~cm}$ into the beach sand rather than 0 to $15 \mathrm{~cm}$ used during normal grooming, thus increasing impacts to the infaunal community. Screens of 6 to $25 \mathrm{~mm}$ were used. Beach grooming has significant effects on the community structure (depressed species richness, abundance, and biomass) of wrack-associated fauna, causing substantial reduction of prey for higher trophic levels (Dugan et al. 2000, 2003, Defeo et al.
2009), and, depending on the spatial scale of grooming $(<1$ to $100 \mathrm{~km})$, the effects can be noticed at scales ranging from weeks to years (Defeo et al. 2009). Mechanical raking (0-3 $\mathrm{cm}$ penetration) for wrack removal on the upper intertidal zone at Padre Island National Seashore, Texas, lowered the mean density and biomass of all macrofauna within $3 \mathrm{~d}$ of raking, and the density and biomass of the amphipod Orchestia grillus and polychaetes up to $10 \mathrm{~d}$ after raking, compared to unraked areas (Engelhard \& Withers 1997).

Removal of wrack with mechanical beach cleaners at 2 tourist beaches reduced the percent total organic matter in the upper beach zone and caused high community stress (i.e. lowered invertebrate diversity, the number of distinctive taxa, and genetic diversity were caused by replacement of species with a higher number of opportunist species), compared to nontourist beaches (Gheskiere et al. 2005). The removal of the top $5 \mathrm{~cm}$ of sand surface with mechanical beach cleaners (Gheskiere et al. 2006) caused significant changes in the total abundance and community structure immediately after cleaning by reducing the abundance of dominant nematode species and harpacticoid copepods, although they recovered completely in the following 2 tide cycles. In Sweden, cleaned beaches had a much lower level of organic carbon than un-cleaned beaches, and the most intensively cleaned beaches had lower total benthic biomass (Malm et al. 2004). However, biodiversity and community structure were not significantly different between cleaned and un-cleaned beaches.

Studies of the effects of beach cleaning in Poland suggested that trampling and mechanical cleaning may have contributed to the disappearance of airbreathing amphipods or sandhoppers from the most frequently visited beaches (Weslawski et al. 2000a,b and citations therein). Furthermore, wrack removal from the upper layer of sand and sand sifting through a $5 \mathrm{~mm}$ sieve effectively removed important food sources for key beach fauna, which are linked to the disappearance of macrofauna and the decline of their predators. Weslawski et al. (2000a) indicated foot traffic (3000 steps $\mathrm{m}^{-2} \mathrm{~d}^{-1}$ ) caused sufficient beach fragmentation and mixed debris with sediment down to 10 to $30 \mathrm{~cm}$.

\section{Sediment removal and placement}

Cleanup operations involving translocation of large volumes of sand (Fig. 4C,D) can be equated with beach nourishment projects, as sand is 
mechanically moved and redistributed on the beach surface, resulting in sizable changes in geomorphology (beach profile, sediment composition, substrate compaction), as well as in temporary changes to the beach inhabitants. Studies following beach nourishment projects and related activities found: (1) slow recovery of an intertidal clam (Donax spp.) population after a nourishment project that replaced the original substrate with sediment containing high levels of shell fragments (Peterson et al. 2000); (2) slow recoveries of macrobenthos after a nourishment project that increased concentration of fine sediments (Rakocinski et al. 1996); (3) large impacts on invertebrate populations for nourishment projects that coincide with the recruitment period of indicator species (Cobb \& Arnold 2008); and (4) low species richness and equitability compared to pre-nourishment levels (Reilly \& Bellis 1983). Major disruptions of the sand beach surface can have significant impacts at population (demography and dynamics), community (species richness), and ecosystem (functional processes, nutrient flux, trophic dynamics) levels (Defeo et al. 2009). Furthermore, reduction in the abundance and biomass of dominant species has been linked to disturbances in the foraging behavior of shorebirds and to reduced habitat productivity (Peterson et al. 2006, Defeo et al. 2009). However, others (Nelson \& Collins 1987) have reported no measurable effects on indicator species attributable to nourishment projects.

Beach nourishment can cause immediate ecological damage to the resident sand beach invertebrate community including complete mortality of resident intertidal biota. Bilodeau \& Bourgeois (2004) found that $2.5 \mathrm{yr}$ after nourishment at the Isles Dernieres barrier islands of Louisiana, the ghost shrimp Callichirus islagrande did not have the large densities seen at reference sites with well-established populations. Only a few juveniles and 1 ovigerous female were found on the nourished beach, indicating that the population showed no indication of recolonization or recruitment. The lack of recolonization was attributed to changes in the sediment composition.

Mechanical disturbance, similar to that produced by many response activities, has been demonstrated to have direct, negative effects on beach macrofaunal populations. Lindquist \& Manning (2001) evaluated impacts of beach nourishment and mechanical redistribution of beach sand (bulldozing) and found significant declines in the abundance of ghost crabs 6 to 8 mo post-bulldozing. Bulldozing also reduced the abundance of mole crabs, though these changes were not statistically significant from controls. Other species (i.e. coquina clams, spionid polychaetes, and amphipods) appeared to have escaped the impacts of bulldozing as their abundances resembled those of control beaches. Peterson et al. (2000) found that both beach nourishment and bulldozing had quantifiable effects on intertidal species 5 to $10 \mathrm{wk}$ posttreatment compared to control beaches. Nourishment reduced the density of 2 dominant taxa, mole crab and Donax spp. by 99 and $86 \%$, respectively, possibly by altering the composition of the substrate, whereas bulldozing reduced the abundance of mole crabs and active ghost crab burrows by 37 and $65 \%$, respectively, probably by changing beach morphology. Peterson et al. (2006) also attributed large mass mortality of benthic macroinfauna to beach filling. Over several months post-treatment, Donax spp. and amphipods had much higher abundances (85 and $89 \%$, respectively), and ghost crab burrow density across the beach was up to twice as high on undisturbed control beaches. In contrast, ghost crab summertime recruitment appeared to have been inhibited on filled beaches. In Australia, beach nourishment caused the elimination of an amphipod with signs of recovery seen only 9 wk later (Jones et al. 2008). In South Africa, excavation of sand to a depth of $30 \mathrm{~cm}$ caused temporary changes in the abundance of macrofauna; this community required 7 to $16 \mathrm{~d}$ to recover following a single disturbance event (Schoeman et al. 2000).

From the literature, it is clear that species susceptibility to impacts from the types of disturbances similar to sand beach treatment methods is largely dependent on individual body size, fragility (soft vs. hard bodies), population turnover rates, and burrowing behavior (deep vs. shallow). Generally, large-scale operations would be more detrimental to species that: (1) brood their young; (2) have a soft exoskeleton; (3) have larger sizes and lower turnover rates; (4) build shallow burrows; (5) have seasonal reproductive cycles that coincide with cleaning activities; (6) occur at high densities in soft, non-compacted sand; and (7) are more closely associated with the substrate, and therefore are more strongly impacted by changes in the structure of the sand matrix (compaction). The fauna comprising sand beach communities along the northern Gulf of Mexico shoreline have many of these characteristics (Shelton \& Robertson 1981, Britton \& Morton 1989), and impacts would be proportional to both the temporal frequency and spatial extent of disturbances. 


\section{RI assignment to the shoreline}

We developed 5 RI categories for the DWH response (shown in Fig. 2 and defined in Table 3) that depended on disturbance type, intensity of the disturbance, the frequency of use, and, based on a literature review, the likely effects of each specific disturbance. The scale is ordinal; actual impacts vary substantially within each category. The compiled data on shoreline treatment methods by segment and date were used to assign a monthly RI category for each segment.

For each month and segment, we derived an estimate for the impacts to sand beach ecosystem services by considering: (1) the levels of intensity of the response activities; (2) where the activity occurred on the beach; (3) whether the area where the activity was applied was spatially extensive or narrowly restricted, and (4) whether the activity was coincident with oiling of the beach (May to September 2010)

For both intermittent and intensive manual removal ( $\mathrm{RI}=1 \mathrm{~A}$ and 2$)$, during the period when the oil was coming ashore, cleanup crews aggressively removed all wrack, whether it was visibly oiled or not. Removal of wrack would have also removed many wrack fauna and their essential habitat. Consequently, in cases where complete or near complete removal of the wrack and associated fauna occurred, there would be a very high loss of the faunal community in the supratidal. Wrack removal or disturbance along $100 \mathrm{~s}$ of $\mathrm{km}$ of contiguous shoreline would have far greater faunal impacts, and ecosystem recovery would be much slower, than those occurring along isolated beaches disturbed on smaller spatial scales (S. Fegley \& J. Michel unpubl.). Later, when monitors

Table 3. Response Injury (RI 1-5) categories, descriptions, intensity by the 4 major disturbance types, and overall impacts on sand beach ecosystem services

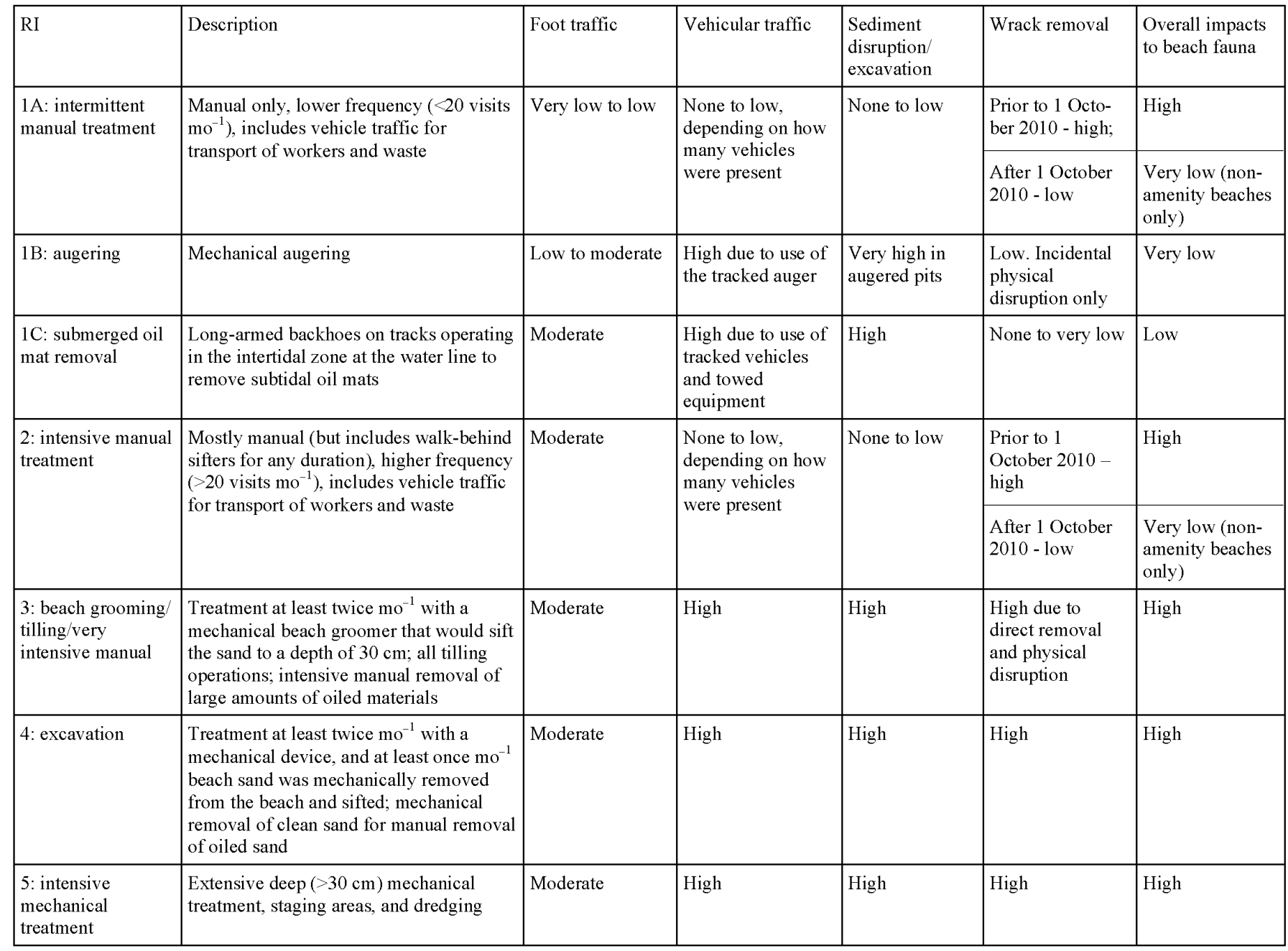


were assigned to the cleanup crews, clean wrack removal was minimized, losses to the faunal community would be reduced, but only to non-amenity beaches, because amenity beaches had historically experienced persistent disturbances associated with foot traffic and beach cleaning. For submerged mat removal $(\mathrm{RI}=1 \mathrm{C})$, which involved tracked backhoes operating in the intertidal zone, losses would be low because the repeated movement of heavy equipment was limited to small areas of each segment.

More intensive treatments defined in Table 3 include beach grooming/tilling/very intensive manual treatment $(\mathrm{RI}=3)$, excavation $(\mathrm{RI}=4)$, and intensive mechanical treatment/staging areas/dredging $(\mathrm{RI}=5)$ and would have induced extensive mortality within the treatment area by displacement, physical trauma, desiccation, and burial during sand storage and replacement. These activities also included ancillary, extensive foot/vehicle traffic and wrack removal. The extensive use of heavy equipment, such as large dump trucks, tracked backhoes, towed sifters, and bulldozers, during the DWH response was unprecedented in terms of both the spatial extent and intensity (Fig. 4B-D).

\section{RESULTS}

Of the $965 \mathrm{~km}$ of sand beaches that were oiled, shoreline treatment was documented on $683 \mathrm{~km}(71 \%)$. In Florida, where nearly $80 \%$ of the oiling on sand beaches was classified as light and $43 \%$ as light persistent, frequent manual treatment $(\mathrm{RI}=2)$ was conducted on $67 \%$ of the shoreline (Fig. 5). However, to meet stringent cleanup endpoints for amenity beaches, beach grooming and tilling were conducted in the supratidal along nearly $60 \mathrm{~km}$ that had heavier oiling initially but was subsequently buried. In Alabama, there were 2 areas where intensive treatment in the supratidal zone was conducted to remove deeply buried oil that caused persistent re-oiling of the beach. In Mississippi, much of the heavier oiling occurred on the outer barrier islands of the Gulf Island National Seashore, where mechanical methods were restricted. Thus, there was proportionally less response-related impact. On the sand beaches of Louisiana, in spite of over $80 \mathrm{~km}$ of heavier persistent oiling, intensive mechanical treatment was conducted on only $32.4 \mathrm{~km}$ because of concerns that mechanical treatment would increase erosion on highly erosional islands. Furthermore, because of the remoteness and difficulty of access to many of the barrier islands in Louisiana, only manual removal (RI = 1 and 2) occurred on $140 \mathrm{~km}$, regardless of the degree of oiling. It was only in 2011 and 2012, when the decision was made to conduct mechanical and intensive manual removal to prevent chronic re-oiling, that $\mathrm{RI}=5$ categories were assigned (Fig. 6).

The maximum RI category for each shoreline segment varied for each year from 2010 to 2014, as did the contiguous extent of treatment in each year (Fig. 6). In 2010, treatments with RI $\geq 2$ were conducted throughout the region, with mechanical excavation conducted late in the year along beaches in Florida and Louisiana. In 2011, persistent buried oil was removed by excavation and sifting along Florida and Alabama beaches, and deep excavations were conducted at Fourchon, Louisiana $(\mathrm{RI}=5$, red lines in
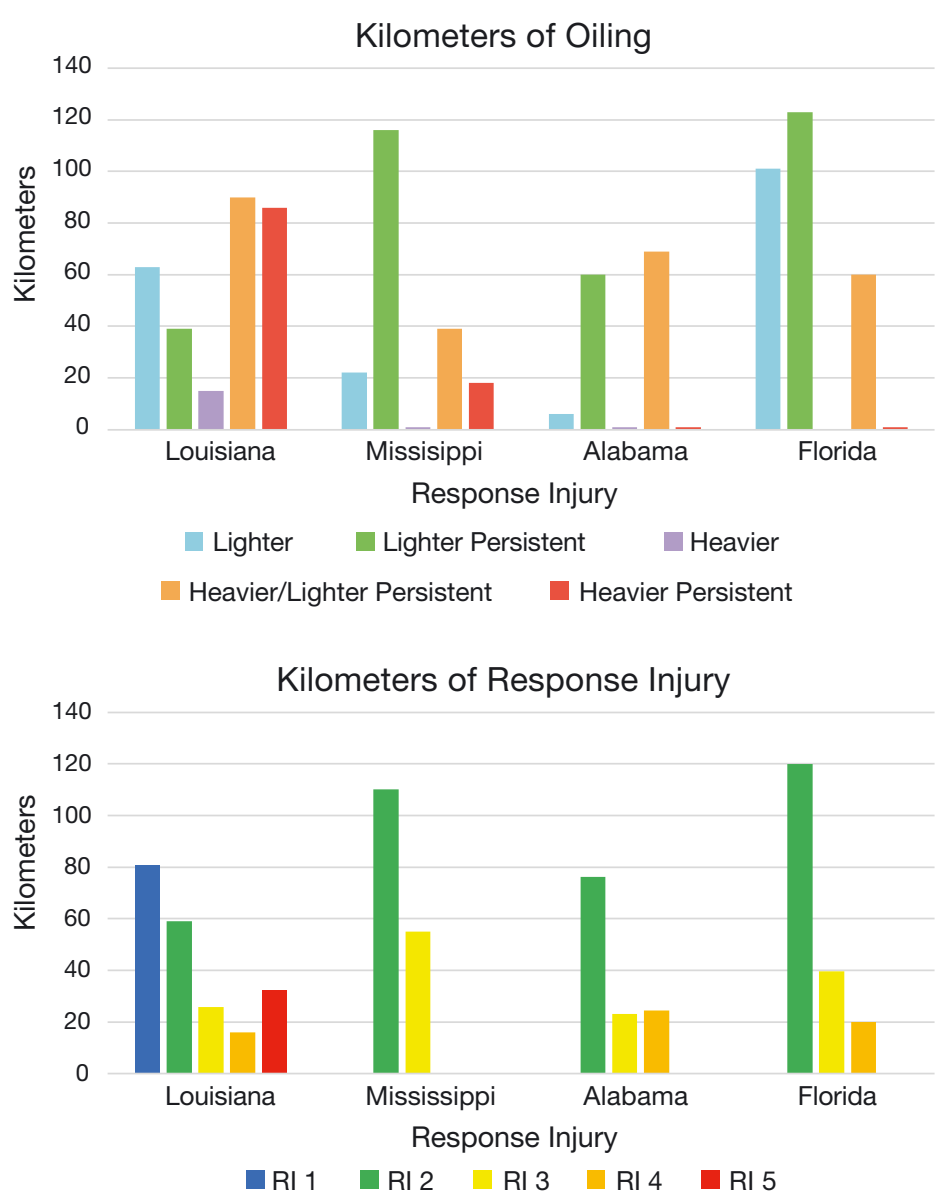

Fig. 5. Length of sand beach by state-assigned (A) oiling category and (B) maximum Response Injury (RI) category. 'Persistent' applies to oiling that persisted on beach for at least $26 \mathrm{wk}$ based on repeat surveys. See Nixon et al. (2016) for more detail on how oiling categories were defined and determined 

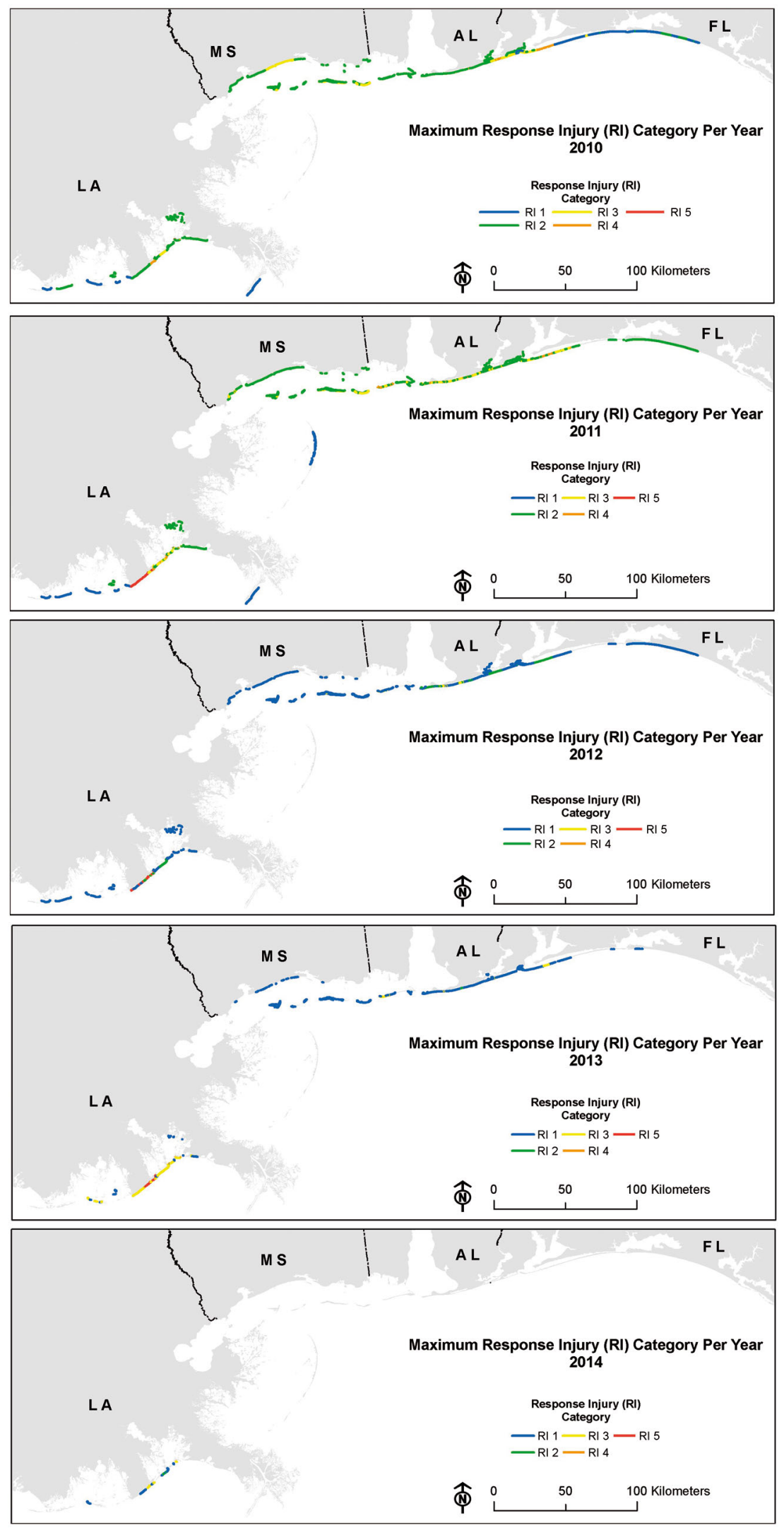

Fig. 6. Maximum Response Injury (RI) category for each beach segment per year
Fig. 6). By 2012, mostly manual removal methods were being conducted, except for some locations in Louisiana. By 2013, intermittent manual removal methods were conducted in Florida to Mississippi, ending in June 2013 when treatment operations were officially terminated on all of these beaches. However, mechanical excavation and intensive manual removal methods were being conducted later in 2013 along Louisiana beaches with persistent buried oil. Louisiana beaches were moved out of response by April 2014, after intensive manual removal of oil on some beaches.

The range of intensity and duration of treatments, and consequently RI and timing for recovery, varied over time and space, which can be illustrated by examining 3 representative areas (Fig. 7). For the lightly oiled beaches of Florida at the eastern extent of shoreline oiling (Fig. 7A), only manual methods were used in all tidal zones, initially at frequencies $>20$ visits $\mathrm{mo}^{-1}$ (RI = 2) until January 2011, when these segments moved into a 'patrol and maintenance' period of less frequent surveys. Workers conducted cleanup operations on every beach segment for 12 mo and on most segments for 19 mo.

Along Alabama beaches, treatment patterns differed. Frequent manual removal only was allowed until early 2011, when there was a push to remove the buried oil. Deep excavations and sifting occurred in the supratidal zone on Dauphin Island, which included large staging and sifting operations, and West Point Island (plotted on the left side of the chart) that lasted from January to March 2011 (Fig. 7B). These types of operations are shown in Fig. 4C. Note the absence of any RI in summer of 2011; these segments were put on 'environmental hold' during bird nesting periods. However, chronic re-oiling on West Point 

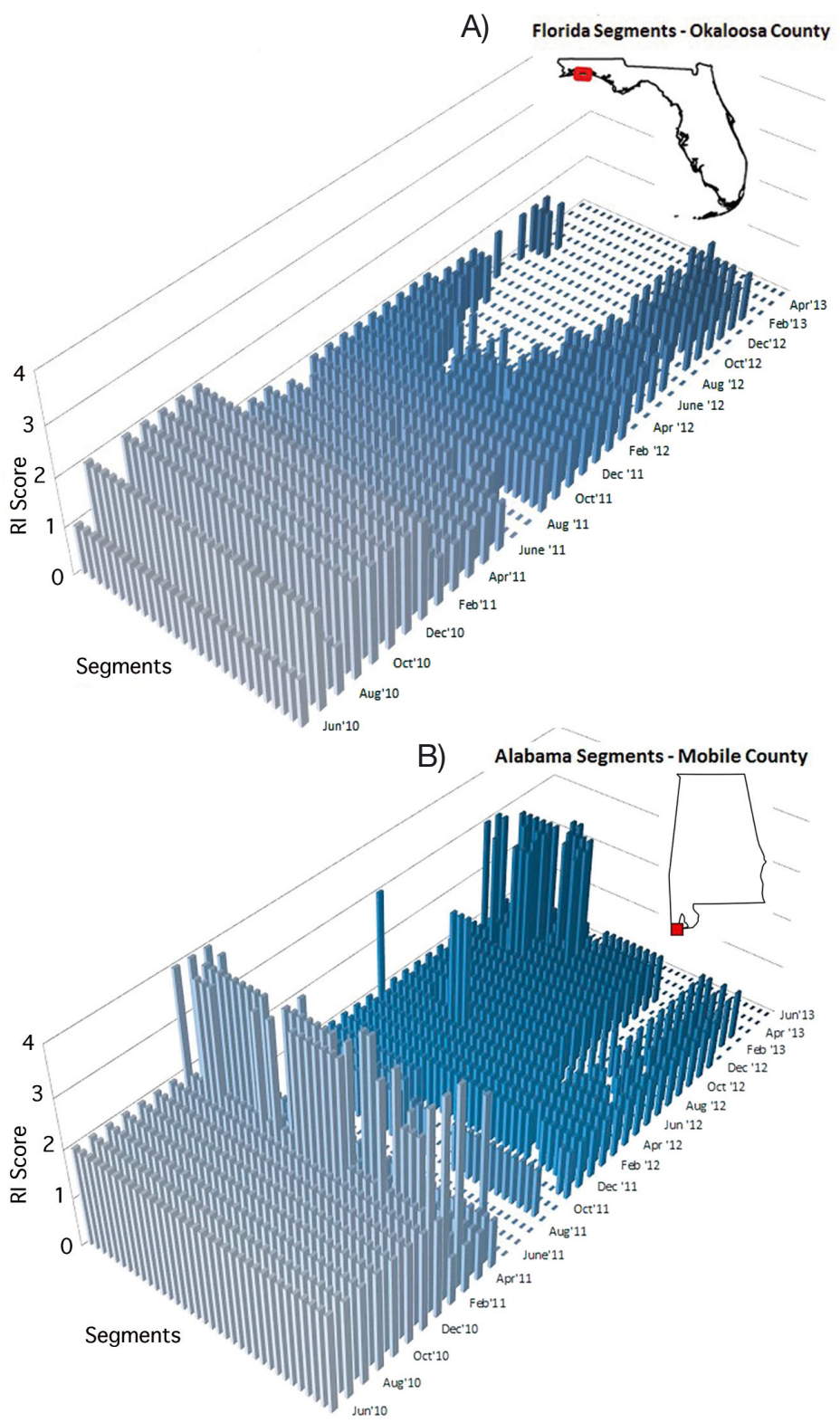

C) Louisiana Segments - Fourchon Beach

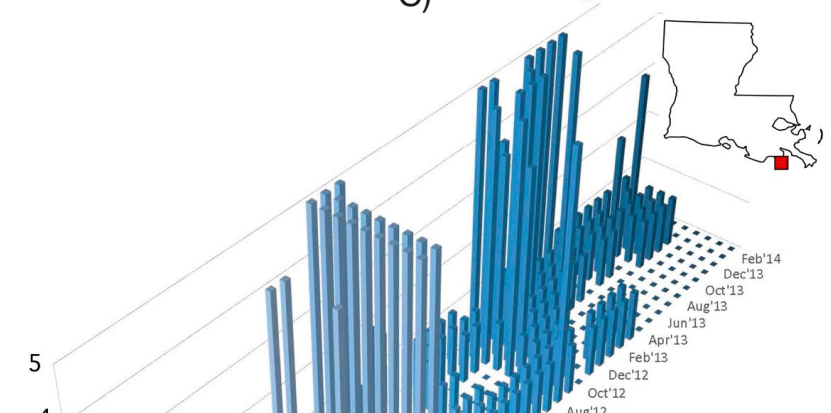

Island triggered the decision to conduct a second period of intensive mechanical treatment starting in December 2012. Therefore, West Point Island received multiple intensive mechanical removal operations, which would re-set any ecosystem recovery that had occurred after the initial oiling or earlier response activities.

Fourchon Beach, Louisiana, received the heaviest oiling and most intensive treatment (Figs. 6 \& $7 \mathrm{C}$ ). The pattern of treatment shows frequent manual removal (which included extensive vehicular traffic on this beach due to limited access) for $>1 \mathrm{yr}$. These efforts were followed by intensive removal of buried oil in all tidal zones that was partially exposed during Tropical Storm 'Lee' in September 2011 and Hurricane 'Isaac' in August 2012.

These 3 examples (Fig. 7) show the varieties in type, spatial continuity, and duration of sand beach treatments following the DWH oil spill that were conducted for a period of 3 to $4 \mathrm{yr}$ after the oil initially stranded onshore. These operations extended the impacts of the response well beyond that expected from oiling alone. Many studies have found that the sand beach invertebrate community recovers within 0.5 to 5 yr post-spill (as summarized in Bejarano et al. 2011 and references therein). Such recoveries, however, would be interrupted by additional impacts resulting from response activities. The RI impacts to the invertebrate community can exceed those associated with oil exposure (Whitfield 2003, de la Huz et al. 2005, Borzone \& Rosa 2009), particularly where intrusive methods were conducted on beaches that were only lightly oiled. The recovery of sand beach invertebrate communities from the DWH spill event was predicted to have been delayed by 2 to $6 \mathrm{yr}$ after the last response action (Deepwater Horizon Natural Resource Damage Assessment Trustees 2016).

\section{DISCUSSION}

This work describes a semi-quantitative approach to incorporate impacts to sand beach habitats resulting from shoreline treatment activities, particularly where such activities are very intensive and frequent for long periods of time and along exten-

Fig. 7. Response Injury (RI) categories for segments in (A) Florida, (B) Alabama, and (C) Louisiana. Shading is used to improve visualization only. Each segment in Florida and Alabama is about $0.5 \mathrm{~km}$ in length, and the entire length shown is $22.6 \mathrm{~km}$ for Florida and $18.4 \mathrm{~km}$ for Alabama. The segments on Fourchon Beach varied in length from 1.7 to $5.5 \mathrm{~km}$, and the entire length shown is $24.5 \mathrm{~km}$ 
sive, contiguous lengths of shoreline. The DWH spill was the first case that we are aware of where response injury was determined in addition to and separate from injury associated with the oil exposure for sand beaches. This approach was needed because of the rapid and deep burial of the oil, which resulted in very intensive disturbances to the supratidal zone during subsequent buried oil removal. Most oil spills do not directly affect the supratidal zone (with notable exceptions); therefore, the supratidal sand beach communities are often not included in impact assessments. Only 1 study specifically mentioned the intensity of cleaning activity (heavy machinery and sediment and wrack removal during the 2002 TV 'Prestige' spill in Spain) in addition to the degree of oiling of the beaches that were studied. Macrofauna of the supratidal zone in heavily oiled areas were even more affected where grooming and wrack removal was intense (de la Huz et al. 2005). With the lack of studies on the impacts of intensive and extensive treatment of oiled beaches, our approach of using response data and the disturbance literature provides the only alternative.

We assigned impacts to beach fauna for the different RI categories in relative terms from very low to very high, and we specifically differentiated between amenity beaches (which have heavy foot traffic from high public use and regular beach manicuring that would remove wrack and shallow fauna) and nonamenity beaches (Table 3). For injury quantification for a specific spill, these impacts would be translated into a percent reduction of ecosystem services, followed by appropriate recovery rates depending on the life histories of the beach macrofauna. For each case, it will be important to consider the timing and areal extent of disturbances during intensive beach treatments in determining the recovery rates. Recovery from disturbances with small footprints can be very quick, with recruitment from adjacent, undisturbed areas, as demonstrated in the small, experimental study of the impacts of a single wrack removal event by Engelhard \& Withers (1997), who found no significant differences in macrofauna density between raked and unraked areas $2 \mathrm{wk}$ after disturbance ended.

During the DWH response, treatments were conducted along extensive lengths of shoreline and throughout the year. The types of equipment used were of similar or greater weight and footprint, and were involved in activities of greater intensity (both spatially and temporally), than those identified in the literature that we evaluated. As the frequency, intensity, and spatial extent of beach disturbance docu- mented in the aftermath of the DWH oiling exceed the disturbances reported by the majority of studies of off-road vehicles, small field experiments, beach grooming, or one-time beach nourishment projects, greater impacts to sand beach communities can be expected to have occurred on Gulf of Mexico beaches receiving treatment. In consideration of all these factors, we argue that our rankings are conservative and may not fully account for even more extensive impacts originating from beach response treatment activities.

The deliberate, intensive treatment of sand beaches, particularly on amenity beaches, reflects the higher valuation of recreation over other ecological services in high public use areas. Where ecological services are deemed as (or more) valuable than recreation, such as on national parks and wildlife refuges, cleanup methods during the DWH response were much less intensive. The perception appears to be that sand beach communities are tolerant to disturbances and have relatively quick and predictable recovery rates. However, Bejarano \& Michel (2016) found few studies of the short-term effects of oil on sand beach invertebrates, and even fewer that documented recovery. Oil exposure and physical disturbances to 965 and $683 \mathrm{~km}$, respectively, of nearly contiguous beach shoreline in the northern Gulf of Mexico likely far exceed the damages documented in individual studies of small areas over short time periods.

The ecological consequences of intensive treatment of sand beaches as we have hypothesized definitely need to be confirmed through well-designed field studies. Results from such studies can and will be used during future responses, to make informed decisions about the tradeoffs in selecting the most appropriate response options. One of the best examples is the study of the severe impacts from use of high-pressure, hot-water flushing on rocky intertidal habitats during the TV 'Exxon Valdez' oil spill versus oil alone, made possible through designation of 'setaside' study sites where no flushing was conducted (Peterson 2001, Shigenaka 2014). Since then, highpressure and high-temperature flushing methods are mostly used only on man-made structures such as seawalls and riprap. Studies of various treatment methods on marshes have well documented the impacts of treatment, with the result that often natural attenuation is the preferred response option (Michel \& Rutherford 2014). Without studies documenting the impacts of aggressive mechanical removal of oil from sand beaches, it will be difficult to argue for leaving some oil for natural attenuation, particularly on beaches with high ecological value. 
Unfortunately, on high-use amenity beaches, the tradeoff analysis is based on economic impacts rather than ecological impact and recovery.

When shoreline treatment is likely to include intensive methods to meet cleanup endpoints, it is important to document the activity as soon as possible. For the DWH response, detailed documentation only occurred during the second year of the response, challenging reconstruction of segment-specific treatment history. Just as teams conduct surveys to document oiling conditions, initially and over time, it is equally important to document the temporal and spatial extent of intensive response actions.

Acknowledgements. This study was funded by the US Department of the Interior, as part of the Deepwater Horizon Natural Resource Damage Assessment conducted by the natural resource trustees. All spreadsheets used to generate the RI by segment are available at: https://www.fws.gov/ doiddata/dwh-ar-documents/908/DWH-AR0296423.pdf.

\section{LITERATURE CITED}

Bejarano AC, Michel J (2016) Oil spills and their impacts on sand beach invertebrate communities: a literature review. Environ Pollut 218:709-722

Bejarano AC, Dunagan H, Michel J (2015) Literature review: effects of oil, shoreline treatment, and physical disturbance on sand beach habitats. (NS_TR.29). DWH Shoreline NRDA Technical Working Group Report. https://www.fws.gov/doiddata/dwh-ar-documents/907/ DWH-AR0259276.pdf

Bilodeau AL, Bourgeois RP (2004) Impact of beach restoration on the deep-burrowing ghost shrimp, Callichirus islagrande. J Coast Res 20:931-936

Borzone CA, Rosa LC (2009) Impact of oil spill and posterior clean-up activities on wrack-living talitrid amphipods on estuarine beaches. Braz J Oceanogr 57:315-323

Britton JC, Morton B (1989) Shore ecology of the Gulf of Mexico. University of Texas Press, Austin, TX

Cobb JC, Arnold B (2008) Assessment of nourishment impacts to beach habitat indicator species in Pinellas County, Florida, October 2005-July 2007. Florida Fish and Wildlife Conservation Commission, St. Petersburg, FL

Colombini I, Chelazzi L (2003) Influence of marine allochthonous input on sandy beach communities. Oceanogr Mar Biol Annu Rev 41:115-159

de la Huz R, Lastra M, Junoy J, Castellanos C, Vieitez J (2005) Biological impacts of oil pollution and cleaning in the intertidal zone of exposed sandy beaches: preliminary study of the 'Prestige' oil spill. Estuar Coast Shelf Sci 65:19-29

Deepwater Horizon Natural Resource Damage Assessment Trustees (2016) Injury to natural resources. Deepwater Horizon oil spill: programmatic damage assessment and restoration plan and programmatic environmental impact statement. Chapter 4. NOAA NMFS, Silver Spring, MD. www.gulfspillrestoration.noaa.gov/restoration-planning/ gulf-plan/

Defeo O, McLachlan A (2005) Patterns, processes and regu- latory mechanisms in sandy beach macrofauna: a multiscale analysis. Mar Ecol Prog Ser 295:1-20

*Defeo O, McLachlan A, Schoeman D, Schlacher T and others (2009) Threats to sandy beach ecosystems: a review. Estuar Coast Shelf Sci 81:1-12

* Dingler JR, Hsu SA, Reiss TE (1992) Theoretical and measured aeolian sand transport on a barrier island, Louisiana, USA. Sedimentology 39:1031-1043

Dugan JE, Hubbard DM, Martin DL, Engle JM and others (2000) Macrofauna communities of exposed sandy beaches on the Southern California Mainland and Channel Islands. Minerals Management Service Report No. 99-0038:339-344. Fifth California Islands Symposium, Santa Barbara, CA

* Dugan JE, Hubbard DM, McCrary MD, Pierson MO (2003) The response of macrofauna communities and shorebirds to macrophyte wrack subsidies on exposed sandy beaches of Southern California. Estuar Coast Shelf Sci 58:25-40

Dugan JE, Defeo O, Jaramillo E, Jones AR and others (2010) Give beach ecosystems their day in the sun. Science 329: 1146

* Dugan JE, Hubbard DM, Page HM, Schimel JP (2011) Marine macrophyte wrack inputs and dissolved nutrients in beach sands. Estuaries Coasts 34:839-850

Engelhard T, Withers K (1997) Biological effects of mechanical beach raking in the upper intertidal zone on Padre Island National Seashore, Texas. Padre Island National Seashore, National Park Service, Department of the Interior, Corpus Christi, TX

Gheskiere T, Vincx M, Weslawski JM, Scapini F, Degraer S (2005) Meiofauna as descriptor of tourism-induced changes at sandy beaches. Mar Environ Res 60:245-265

Gheskiere T, Magda V, Greet P, Steven D (2006) Are strandline meiofaunal assemblages affected by a once-only mechanical beach cleaning? Experimental findings. Mar Environ Res 61:245-264

Hooper C (1981) The Ixtoc I oil spill: the federal scientific response. U.S. Dept. of Commerce, National Oceanic and Atmospheric Administration, Office of Marine Pollution Assessment, Boulder, CO

Irlandi E, Arnold B (2008) Assessment of nourishment impacts to beach habitat indicator species. Grant Agreement No. 05042. Florida Fish and Wildlife Conservation Commission, St. Petersburg, FL

Janssen G, Mulder S (2005) Zonation of macrofauna across sandy beaches and surf zones along the Dutch coast. Oceanologia 47:265-282

Jones A, Murray A, Lasiak T, Marsh R (2008) The effects of beach nourishment on the sandy-beach amphipod Exoediceros fossor: impact and recovery in Botany Bay, New South Wales, Australia. Mar Ecol 29:28-36

Junoy J, Castellanos C, Viéitez J, de la Huz M, Lastra M (2005) The macroinfauna of the Galician sandy beaches (NW Spain) affected by the Prestige oil-spill. Mar Pollut Bull 50:526-536

* Junoy J, Castellanos C, Viéitez JM, Riera R (2013) Seven years of macroinfauna monitoring at Ladeira beach (Corrubedo Bay, NW Spain) after the Prestige oil spill. Oceanologia 55:393-407

Junoy J, Castellanos C, Bernardo-Madrid R, Riera R, Vieitez $\mathrm{J}$ (2014) Macroinfaunal recovery on the beach most severely affected by the 'Prestige' oil spill (O Rostro, Galicia, north-west Spain). J Mar Biol Assoc UK 94:17-24 Kindinger ME (1981) Impacts of the Ixtoc I oil spill on the 
community structure of the intertidal and subtidal infauna along south Texas beaches. MSc thesis, Corpus Christi State University, Corpus Christi, TX

Kluft JM, Ginsberg HS (2009) The effect of off-road vehicles on barrier beach invertebrates at Cape Cod and Fire Island national seashores. Tech Rep NPS/NER/NRTR2009/138. National Park Service, Boston, MA

Lindquist N, Manning L (2001) Impacts of beach nourishment and beach scraping on critical habitat and productivity of surf fishes. NC Fisheries Resource Grant Program, Morehead City, NC

Lucrezi S, Schlacher TA (2010) Impacts of off-road vehicles (ORVs) on burrow architecture of ghost crabs (Genus Ocypode) on sandy beaches. Environ Manag 45: 1352-1362

Malm T, Råberg S, Fell S, Carlsson P (2004) Effects of beach cast cleaning on beach quality, microbial food web, and littoral macrofaunal biodiversity. Estuar Coast Shelf Sci 60:339-347

McLachlan A, Jaramillo E (1995) Zonation on sandy beaches. Oceanogr Mar Biol Annu Rev 33:305-335

McLachlan A, Brown AC (2006) The ecology of sandy shores, $2^{\text {nd }}$ edn. Academic Press, Elsevier, Burlington, MA

Michel J, Rutherford N (2014) Impacts, recovery rates, and treatment options for spilled oil in marshes. Mar Pollut Bull 82:19-25

* Michel J, Owens EH, Zengel S, Graham A and others (2013) Extent and degree of shoreline oiling: Deepwater Horizon oil spill, Gulf of Mexico, USA. PLOS ONE 8:e65087

Michel J, Fegley S, Dahlin J (2015) Deepwater Horizon sand beach injury assessment. (NS_TR.24). DWH Shoreline NRDA Technical Working Group Report. https://pubdwhdatadiver.orr.noaa.gov/dwh-ar-documents/894/DWHAR0104418.pdf

Moffett MD, McLachlan A, Winter PED, De Ruyck AMC (1998) Impact of trampling on sandy macrofauna. J Coast Conserv 4:87-90

Nelson WG, Collins GW (1987) Effects of beach renourishment on the benthic macrofauna and the fishes of the nearshore zone at Sebastian Inlet state recreation area. Report No. 87-14. Florida Institute of Technology, Melbourne, FL

Nixon Z, Zengel S, Baker M, Steinhoff M, Fricano G, Rouhani S, Michel J (2016) Shoreline oiling from the Deepwater Horizon oil spill. Mar Pollut Bull 107:170-178

Noriega R, Schlacher TA, Smeuninx B (2012) Reductions in ghost crab populations reflect urbanization of beaches and dunes. J Coast Res 28:123-131

"Peterson C (2001) The "Exxon Valdez" oil spill in Alaska: acute, indirect and chronic effects on the ecosystem. Adv Mar Biol 39:1-103

Peterson C, Hickerson D, Johnson G (2000) Short-term consequences of nourishment and bulldozing on the dominant large invertebrates of a sandy beach. J Coast Res 16:368-378

* Peterson CH, Bishop MJ, Johnson GA, D'Anna LM, Manning LM (2006) Exploiting beach filling as an unaffordable experiment: benthic intertidal impacts propagating upwards to shorebirds. J Exp Mar Biol Ecol 338:205-221

Raffaelli D, Karakassis I, Galloway A (1991) Zonation schemes on sandy shores: a multivariate approach. J Exp Mar Biol Ecol 148:241-253

Rakocinski CF, Heard RW, Simons T, Gledhill D (1991) Macroinvertebrate associations from the beaches of se- lected barrier islands in the northern Gulf of Mexico: important environmental relationships. Bull Mar Sci 48: 689-701

Rakocinski C, Heard R, LeCroy S, McLelland J, Simons T (1996) Responses by macrobenthic assemblages to extensive beach restoration at Perdido Key, FL. J Coast Res 12:326-353

Rakocinski CF, LeCroy SE, McLelland JA, Heard RW (1998a) Nested spatiotemporal scales of variation in sandy-shore macrobenthic community structure. Bull Mar Sci 63:343-362

Rakocinski CF, LeCroy SE, McLelland JA, Heard RW (1998b) Macrobenthic effects of hurricanes Opal and Erin within the Gulf Islands National Seashore. U.S. Dept. of the Interior, Ocean Springs, MS

Reilly JF, Bellis V (1983) The ecological impact of beach nourishment with dredged materials on the intertidal zone at Bogue Banks, North Carolina. Miscellaneous Report. U.S. Army Corps of Engineers, Coastal Engineering Research Center, Fort Belvoir, VA

Schlacher TA, Thompson L, Price S (2007) Vehicles versus conservation of invertebrates on sandy beaches: mortalities inflicted by off-road vehicles on ghost crabs. Mar Ecol 28:354-367

* Schlacher TA, Richardson D, McLean I (2008) Impacts of offroad vehicles (ORVs) on macrobenthic assemblages on sandy beaches. Environ Manag 41:878-892

* Schoeman D, McLachlan A, Dugan J (2000) Lessons from a disturbance experiment in the intertidal zone of an exposed sandy beach. Estuar Coast Shelf Sci 50:869-884

Shelton CR, Robertson PB (1981) Community structure of intertidal macrofauna of two surf-exposed Texas sandy beaches. Bull Mar Sci 31:833-842

Shigenaka G (2014) Twenty-five years after the Exxon Valdez oil spill: NOAA's scientific support, monitoring, and research. NOAA Office of Response and Restoration, Seattle, WA

Tunnell J, Dokken Q, Kindinger M, Thebeau L (1982) Environmental impact of IXTOC I oil spill on south Texas sandy beaches: infauna and shorebirds. International Symposiium Ixtoc-1. Corpus Christi State University, Corpus Christi, TX

USACE (U.S. Army Corps of Engineers) (1989) Environmental engineering for coastal protection. Engineer Manual 1110-2-1204. U.S. Army Corps of Engineers, Washington, DC

van der Merwe D, van der Merwe D (1991) Effects of offroad vehicles on the macrofauna of a sandy beach. S Afr J Sci 87:210-213

Weslawski J, Stanek A, Siewert A, Beer N (2000a) The sandhopper (Talitrus saltator, Montagu 1808) on the Polish Baltic Coast. Is it a victim of increased tourism? Oceanol Stud 29:77-87

Weslawski J, Urban-Malinga B, Kotwicki L, Opalinski K, Szymelfenig M, Dutkowski M (2000b) Sandy coastlinesAre there conflicts between recreation and natural values? Oceanol Stud 29:5-18

Whitfield J (2003) How to clean a beach. Nature 422: 464-466

*Yáñez-Arancibia A, Day JW (2004) Environmental subregions in the Gulf of Mexico coastal zone: the ecosystem approach as an integrated management tool. Ocean Coast Manag 47:727-757

Submitted: March 10, 2016; Accepted: September 28, 2016

Proofs received from author(s): November 11, 2016 